\title{
Impact of thickness and heat treatment on some physical properties of thin $\mathrm{Cu}_{2} \mathrm{SnS}_{3}$ films
}

\author{
Iqbal S. Naji, Hoolya Abdulrasool
}

Department of Physics, College of Science, University of Baghdad, Baghdad, Iraq

E-mail: moon_moonaaaa@yahoo.com

\begin{abstract}
Copper tin sulfide $\left(\mathrm{Cu}_{2} \mathrm{SnS}_{3}\right)$ thin films have been grown on glass substrate with different thicknesses $(500,750$ and 1000) nm by flash thermal evaporation method after prepare its alloy from their elements with high purity. The as-deposited films were annealed at $473 \mathrm{~K}$ for $1 \mathrm{~h}$. Compositional analysis was done using Energy dispersive spectroscopy (EDS). The microstructure of CTS powder examined by SEM and found that the large crystal grains are shown clearly in images. XRD investigation revealed that the alloy was polycrystalline nature and has cubic structure with preferred orientation along (111) plane, while as deposited films of different thickness have amorphous structure and converted to polycrystalline with annealing temperature for high thickness. AFM measurements showed that the grain size of the films was increasing by annealing. The ultraviolet- visible absorption spectrum measurement indicated that the films have a direct energy band gap. $E_{g}$ decrease with thickness and increase with annealing.
\end{abstract}

Key words

$\mathrm{Cu}_{2} \mathrm{SnS}_{3}$, flash thermal evaporation, $X$-ray, AFM, SEM.

Article info.

Received: Mar. 2016

Accepted: Mar. 2016

Published: Sep. 2016

$$
\begin{aligned}
& \text { تأثير السمك والمعاملة الحرارية على بعض الخصائص الفيزيائية لاغشية Cu2 } \\
& \text { اقبال سهام ناجي، هوليا عبدالرسول لفته } \\
& \text { قسم الفيزياء، كلية العلوم، جامعة بغداد، بغداد، العراق }
\end{aligned}
$$

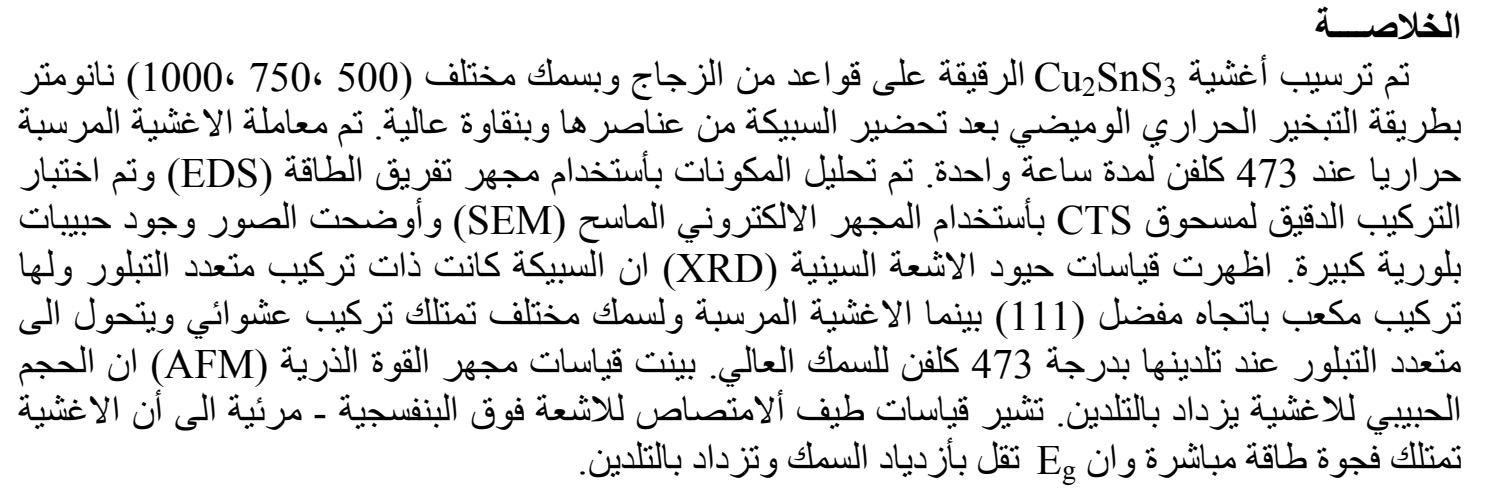

\section{Introduction}

The energy crisis and environment problems becoming more and more serious, it is very urgent to explore new energy resource, Solar energy is a promising new energy resource which is clean and sustainable [1]. In recent years, there has been a great deal of interest in the study of nontoxic semiconductors from both the fundamental and technological points of view for solar cell materials [2]. The I-IV-VI ternary group of semiconductor was attracted much attention because of their interesting properties [3]. The multiple local coordination geometry around the 
metal ion center and the catenation ability of sulfur for I-IV-VI ternary chalcogenides, many kinds of $\mathrm{Cu}-\mathrm{Sn}-\mathrm{E}(\mathrm{S}, \mathrm{Se})$ have been synthesized [4]. The ternary semiconductors $\mathrm{Cu}_{2} \mathrm{SnX}_{3} \quad(\mathrm{X}=\mathrm{S}, \mathrm{Se})$ are found frequently as secondary phases in synthesized $\mathrm{Cu}_{2} \mathrm{ZnSnS}_{4}$ and $\mathrm{Cu}_{2} \mathrm{ZnSnSe}_{4}$ samples ,as candidates for low-cost thinfilm solar-cell absorbers, quaternary semiconductors $\mathrm{Cu}_{2} \mathrm{ZnSnS}_{4}$ (CZTS) and $\mathrm{Cu}_{2} \mathrm{ZnSnSe}_{4}$ (CZTSe) have been studied intensively in the past five years [5]. The research groups have been focusing their attention to this compound to increase the efficiency in the near future, despite the advantages that come from CZTS, it shows a complex structure and requires very controlled growth conditions, If this process starts with metallic precursors, intermediate binary and ternary sulfides are formed, these compounds will remain after the end of the growth process if the composition and the sulfurization conditions are carefully controlled, among these ternary sulfides, $\mathrm{Cu}_{2} \mathrm{SnS}_{3}$ is the most relevant compound[6]. The ternary $\mathrm{Cu}-\mathrm{Sn}-\mathrm{S}$ (CTS) system belongs to group I-IV-VI semiconductors which have attracted great attention because it's a potential earth abundant absorber material for photovoltaic devices application, light emitting diode, nonlinear optical materials, photo catalytic activity and lithium-ion electrode materials due to suitable optoelectronic properties and attractive raw-material features depending on its crystal structure, and their outstanding optical-thermalmechanical properties $[2,7,8]$. CTS consists of low-cost non-toxic and abundant elements [8], and it is a ptype[9], with narrow direct band-gap semiconductor [10,11] ranging from $0.87-1.77 \mathrm{eV}$ and exhibits high optical absorption coefficient $\left(>10^{4} \mathrm{~cm}^{-1}\right)$ [12]. Therefore $\mathrm{Cu}_{2} \mathrm{SnS}_{3}$ used in the heart of a thin films solar cell as the absorber layer which efficiently harvests sunlight [13].
$\mathrm{Cu}_{2} \mathrm{SnS}_{3}$ exists in a number of polymorphs, One of them, the cubic $\mathrm{Cu}_{2} \mathrm{SnS}_{3}$, is a high temperature polymorph $\left(>775^{\circ} \mathrm{C}\right)$ and is not likely to appear in kesterite thin films due to the fact that typical growth temperatures are limited to $600{ }^{\circ} \mathrm{C}$ [3].

This paper reports the impact of thickness and annealing temperatures on the structural, morphological, and optical properties of CTS thin films which deposited by flash thermal evaporation technique.

\section{Experimental procedure}

CTS alloy has been prepared with appropriate weight percentage (2:1:3) using high purity elemental $\mathrm{Cu}$ (Carloerba), Sn (England), and S (Ferac Berlin) which about $99.999 \%$. The elemental analysis of this alloy was carried out by using energy-dispersive X-ray spectroscopy (EDS) detector (Bruker nano $\mathrm{GmbH}$, Germany) coupled with SEM model (Inspect S50 system) which give morphology of this alloy, also X-ray powder diffraction (XRD) investigated by (Miniflex II Rigaku company, Japan). Xray diffractometer using $\mathrm{Cu} \mathrm{K}_{\alpha}$ radiation $(\lambda=1.5418 \mathrm{~A}) \cdot \mathrm{Cu}_{2} \mathrm{SnS}_{3}$ alloy used as a source material to prepare thin films which deposited by flash thermal evaporation technique with different thickness with rate of deposition equal to $3.808 \mathrm{~nm} / \mathrm{min}$ at high vacuum $\left(10^{-5} \mathrm{mbar}\right)$ using Edward Auto 360 vacuum coating unit.

The annealing process was carried out to prepare films in vacuum at $473 \mathrm{~K}$ for 1h. The structures of as deposited and annealed films were investigated. Also, topography of the films surface were studied by employing atomic force microscope (AFM) (AA3000 Scanning probe Microscope SPM, tip NSC35/AIBS from Angstrom Advanced Inc., USA). UV-visible absorption spectra were obtained using a Shimadzu (UV-1650 PC) spectrophotometer over the wavelength range (300-1100) $\mathrm{nm}$ and calculated the optical properties of as 
deposited and annealed films with different thicknesses $(500,750$, and 1000) $\mathrm{nm}$.

\section{Results and discussion}

\section{Composition analysis by EDS} technique

Energy Dispersive X-ray Spectroscopy (EDS) technique was used to determine the amount or concentration of the elements $(\mathrm{Cu}, \mathrm{Sn}, \mathrm{S})$ in the alloy depending on the standard of these elements. Fig.1 shows
EDS spectrum of CTS alloy. From this figure the peaks of $\mathrm{Cu}, \mathrm{Sn}$, and $\mathrm{S}$ elements can be recognized, this means that the alloy quality is good since there is no presence of other elements observed. Table 1 illustrates that the real phase of the sample equal to $60 \%$ and the secondary phase equal to $40 \%$, and the $\mathrm{S}$ ratio equal to 2.09 , this ratio doesn't reach to the essential value of the compound that equal to 3, So CTS is rich with Sn and poor with $\mathrm{Cu}$ and $\mathrm{S}$.

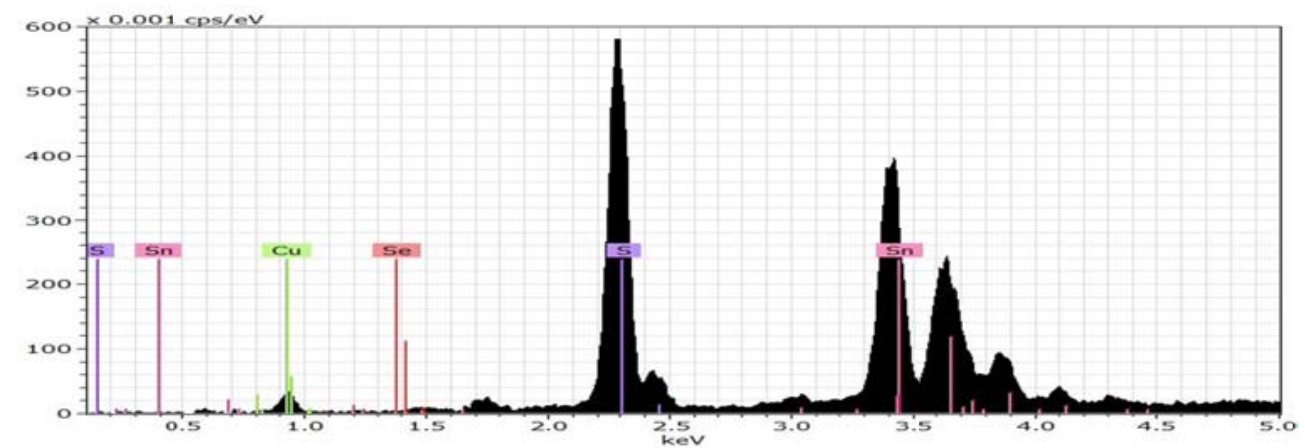

Fig. 1: EDS chart of CTS compound.

Table 1: Elemental compositions and ratios of real and secondary phases of CTS compound from EDS data.

\begin{tabular}{|c|c|c|c|c|c|c|c|c|c|}
\hline \multirow{2}{*}{ Sample } & \multicolumn{3}{|c|}{ Wt ratio $\%$ of EDS } & \multicolumn{3}{|c|}{$\begin{array}{c}\text { Percentage Ratio \% of } \\
\text { EDS }\end{array}$} & \multirow[t]{2}{*}{$\begin{array}{l}\text { Formula Exp. } \\
\text { of moles }\end{array}$} & \multirow[t]{2}{*}{$\begin{array}{l}\text { Real phase } \\
\text { of formed } \\
\text { film } \%\end{array}$} & \multirow[t]{2}{*}{$\begin{array}{l}\text { Secondary } \\
\text { phase } \%\end{array}$} \\
\hline & $\mathrm{Cu}$ & $\mathrm{Sn}$ & $\mathrm{S}$ & $\mathrm{Cu}$ & $\mathrm{Sn}$ & $\mathrm{S}$ & & & \\
\hline $\mathrm{Cu}_{2} \mathrm{SnS}_{3}$ & 20.35 & 45.73 & 35.36 & 20.06 & 45.07 & 34.85 & $\mathrm{Cu}_{1.2} \mathrm{Sn}_{2.7} \mathrm{~S}_{2.09}$ & 60 & 40 \\
\hline
\end{tabular}

\section{Structure measurements}

\subsection{Scanning electron microscopy} (SEM)

The surface morphology results of prepared CTS alloy was studied by SEM images with two magnification value as shown in Fig. 2. This figure show that the surface with black background, compressed and nubby grains. Also there are some white grains that may be belong to $\mathrm{Sn}$ existence, this result agrees with Zhao and Cheng [9].
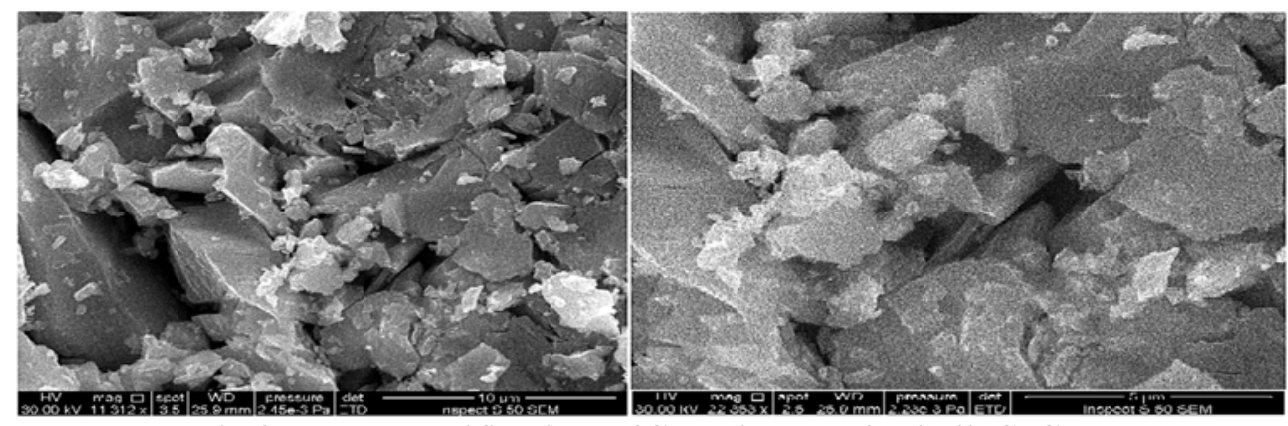

Fig.2: Two magnification of SEM images for bulk CTS. 


\subsection{X-ray diffraction measurements}

XRD using to investigate the structure of semiconductor material and to observe the structure changes after evaporation. The effect of films thickness $(500,750$ and $1000) \mathrm{nm}$, and the heat treatment $(473 \mathrm{~K})$ on the films structure has been studied. X-ray diffraction pattern of bulk CTS showed that the sample has a polycrystalline structure as shown in Fig.3. The results of bulk CTS reveals that the cubic phase appears with preferred orientation along (111) direction at $2 \theta$ around $28.326^{\circ}$ dominates, the data compared with JCPDS Card number 01089-2877, this result is agreement with Liang et al. [3] and Fernandes et al.[5].

The structural parameters like inter planer spacing, miller indices, and crystallite size for CTS alloy are shown in Table 2.

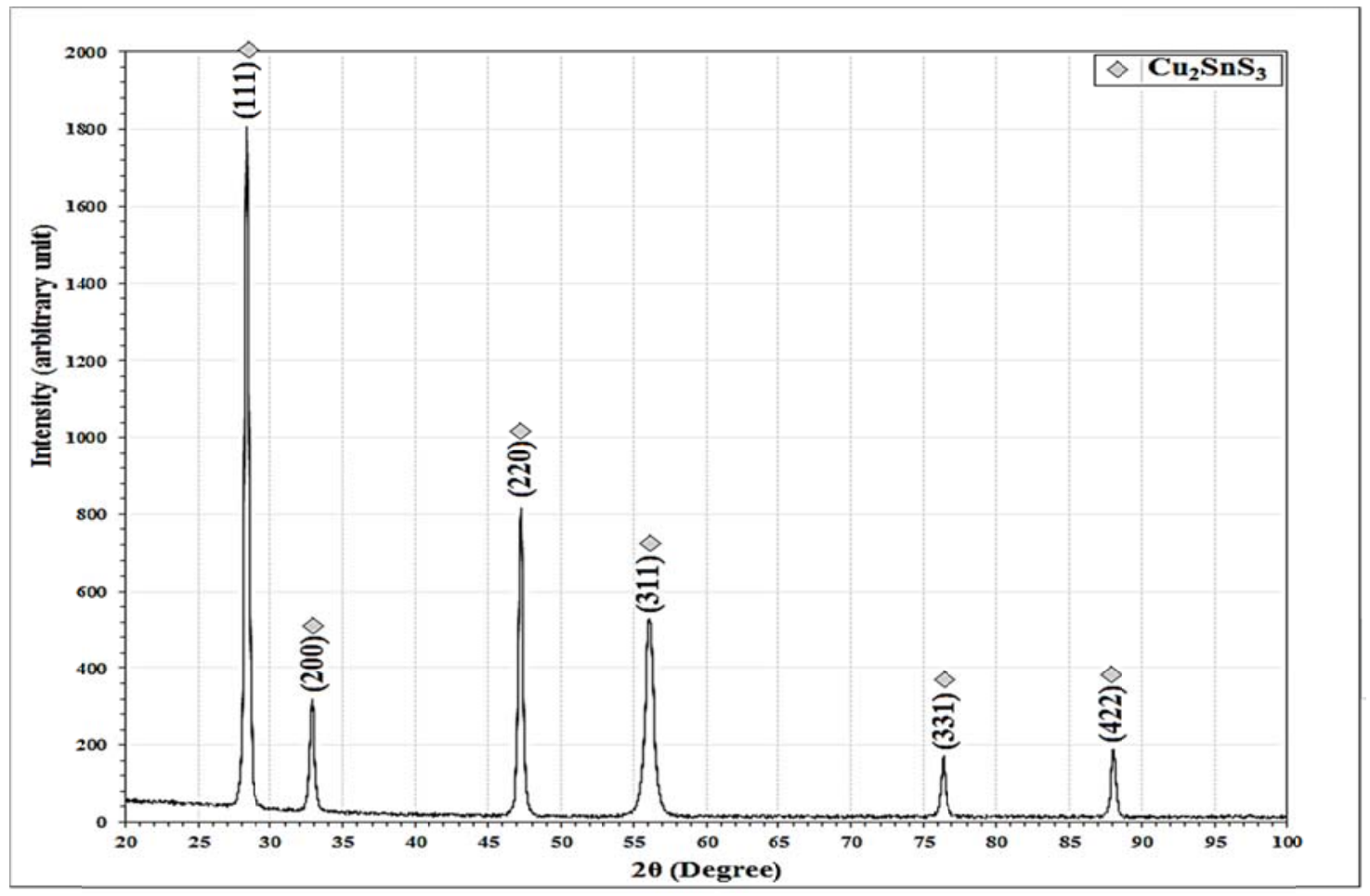

Fig. 3: X-ray diffraction pattern for CTS powder.

Table 2: Structural parameters viz. inter-planer spacing, miller indices, and crystallite size of bulk CTS.

\begin{tabular}{|c|c|c|c|c|c|c|c|}
\hline Sample & $2 \theta$ (Deg.) & $\begin{array}{c}\mathrm{d}_{\text {hkl }} \text { Exp. } \\
(\AA)\end{array}$ & $\begin{array}{c}\mathrm{d}_{\text {hkl }} \text { Std } \\
.(\AA)\end{array}$ & hkl & $\begin{array}{c}\text { FWHM } \\
(\text { Deg. })\end{array}$ & $\begin{array}{c}\text { Crys.Size } \\
(\mathrm{nm})\end{array}$ & Phase \\
\hline \multirow{4}{*}{$\mathrm{Cu}_{2} \mathrm{SnS}_{3}$} & 28.3267 & 3.1481 & 3.13509 & $(111)$ & 0.3060 & 26.8 & Cubic-Cu $\mathrm{Cu}_{2} \mathrm{SnS}_{3}$ \\
\cline { 2 - 8 } & 32.8738 & 2.7223 & 2.71507 & $(200)$ & 0.3530 & 23.5 & Cubic- $\mathrm{Cu}_{2} \mathrm{SnS}_{3}$ \\
\cline { 2 - 8 } & 47.2520 & 1.9221 & 1.91984 & $(220)$ & 0.3290 & 26.4 & $\mathrm{Cubic}-\mathrm{Cu}_{2} \mathrm{SnS}_{3}$ \\
\cline { 2 - 8 } & 56.1140 & 1.6377 & 1.63725 & $(311)$ & 0.6350 & 14.2 & $\mathrm{Cubic}_{2} \mathrm{Cu}_{2} \mathrm{SnS}_{3}$ \\
\cline { 2 - 8 } & 76.3567 & 1.2462 & 1.24576 & $(331)$ & 0.3530 & 28.6 & $\mathrm{Cubic}-\mathrm{Cu}_{2} \mathrm{SnS}_{3}$ \\
\cline { 2 - 8 } & 88.0380 & 1.1085 & 1.10842 & $(422)$ & 0.3530 & 31.3 & $\mathrm{Cubic}_{2} \mathrm{Cu}_{2} \mathrm{SnS}_{3}$ \\
\hline
\end{tabular}

The X-ray diffraction pattern of as deposited and annealed $\mathrm{Cu}_{2} \mathrm{SnS}_{3}$ films for different thickness $(500,750$ and
1000) $\mathrm{nm}$ are shown in Fig. 4 and Table 3. 

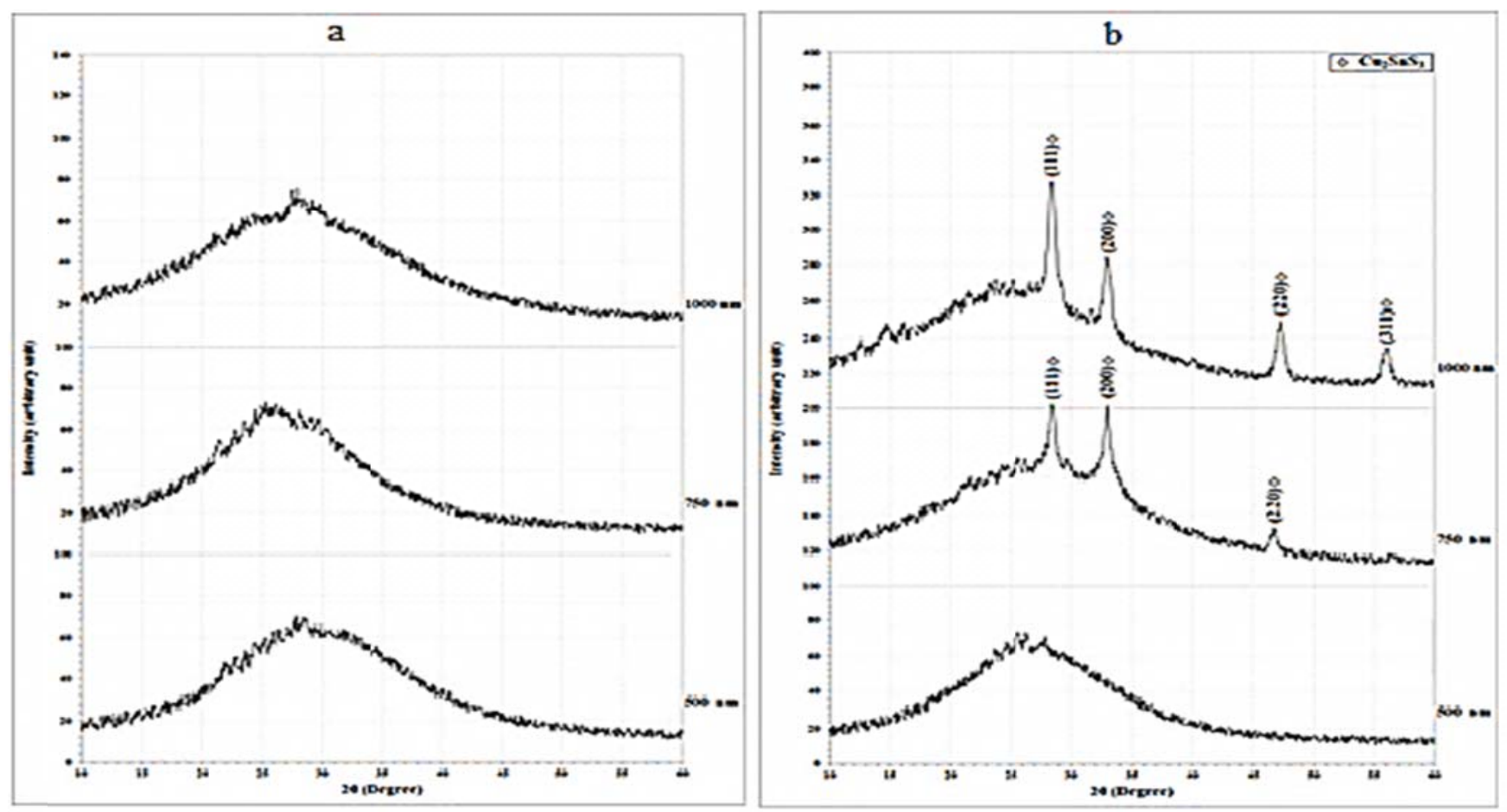

Fig. 4: X-ray diffraction pattern for CTS films at different thickness a-as deposited b-annealed at $473 \mathrm{~K}$.

As deposited CTS films for different thickness show an amorphous structure. Annealed CTS films with thickness 500 $\mathrm{nm}$ also show an amorphous structure, while the annealed film with thickness $750 \mathrm{~nm}$ have three peaks with good intensity corresponding to (111), (200), and (220) for cubic structure around $2 \Theta$ equal to $28.460^{\circ}, 32.976^{\circ}$, and $46.701^{\circ}$ respectively. The annealed films with thickness $1000 \mathrm{~nm}$ have four peaks appeared with high intensity corresponding to (111), (200), (220), and (311) around $2 \Theta$ equal to $28.420^{\circ}$, $32.972^{\circ}, \quad 47.232^{\circ}, \quad$ and $56.013^{\circ}$ respectively. However there is no binary phase formed, this means the compositions are good, and there is no re-evaporation of $\mathrm{S}$ from the growing films. Generally, CTS thin films were amorphous and become polycrystalline by annealing and have a good peaks than as deposited films because annealing enhanced the properties of films, the peak intensity increased when thickness increased because of thickness make the matter of films more compact then reduce the defect in the these films.

Table 3: Structural parameters viz. inter-planar spacing, miller indices, and crystallite size of CTS films annealed at $473 \mathrm{~K}$ with different thicknesses.

\begin{tabular}{|c|c|c|c|c|c|c|c|}
\hline \multirow{2}{*}{$\mathrm{t}(\mathrm{nm})$} & $2 \theta$ (Deg.) & $\begin{array}{c}\mathrm{d}_{\text {hkl }} \text { Exp. } \\
(\AA)\end{array}$ & $\begin{array}{c}\mathrm{d}_{\mathrm{hkl}} \text { Std. } \\
(\AA)\end{array}$ & $\mathrm{hkl}$ & $\begin{array}{c}\text { FWHM } \\
(\text { Deg. })\end{array}$ & $\begin{array}{c}\text { Crys.Size } \\
(\mathrm{nm})\end{array}$ & Phase \\
\hline 500 & - & - & - & - & - & - & Amorphous \\
\hline \multirow{3}{*}{750} & 28.4600 & 3.1337 & 3.13509 & $(111)$ & 0.6350 & 12.9 & $\mathrm{Cubic}-\mathrm{Cu}_{2} \mathrm{SnS}_{3}$ \\
\cline { 2 - 8 } & 32.9760 & 2.7141 & 2.71507 & $(200)$ & 0.3760 & 22.0 & $\mathrm{Cubic}_{2}-\mathrm{Cu}_{2} \mathrm{SnS}_{3}$ \\
\cline { 2 - 8 } & 46.7012 & 1.9435 & 1.91984 & $(220)$ & 0.5140 & 16.8 & $\mathrm{Cubic}_{2}-\mathrm{Cu}_{2} \mathrm{SnS}_{3}$ \\
\hline \multirow{3}{*}{1000} & 28.4200 & 3.1380 & 3.13509 & $(111)$ & 0.7290 & 11.2 & $\mathrm{Cubic}_{2}-\mathrm{Cu}_{2} \mathrm{SnS}_{3}$ \\
\cline { 2 - 8 } & 32.9720 & 2.7144 & 2.71507 & $(200)$ & 0.7240 & 11.4 & $\mathrm{Cubic}_{2} \mathrm{Cu}_{2} \mathrm{SnS}_{3}$ \\
\cline { 2 - 8 } & 47.2320 & 1.9228 & 1.91984 & $(220)$ & 0.7210 & 12.0 & $\mathrm{Cubic}_{2} \mathrm{Cu}_{2} \mathrm{SnS}_{3}$ \\
\cline { 2 - 8 } & 56.0130 & 1.6404 & 1.63725 & $(311)$ & 0.7340 & 12.3 & $\mathrm{Cubic}_{-} \mathrm{Cu}_{2} \mathrm{SnS}_{3}$ \\
\hline
\end{tabular}




\subsection{Atomic Force Microscopy (AFM)}

AFM is a useful technique for determining surface topography and regarded the most effective ways due to its high resolution and powerful analysis. The three dimensional AFM images and histogram of as deposited and annealed CTS thin films prepared by flash thermal evaporation with thickness equal to 1000 $\mathrm{nm}$ are shown in Fig. 5 and Table 4. These images revealed that the film is covered by uniform, homogeneous and tightly adherent, nano crystallites, having spherical grains without any voids or cracks.
Also these images show that the CTS thin films have continuous grnular mrphology. The spherical grains for CTS was reported by Tiwari et al. [12], who they prepared the CTS films by direct liquid coating.

The grain size for as deposited CTS films increases from $87.78 \mathrm{~nm}$ to 102.02 $\mathrm{nm}$ when film annealed at $473 \mathrm{~K}$. This behavior occur due to structure improvement. while the root mean square roughness (RMS) decrease as summarized in Table 4, this means the average roughness decrease with annealing temperature.

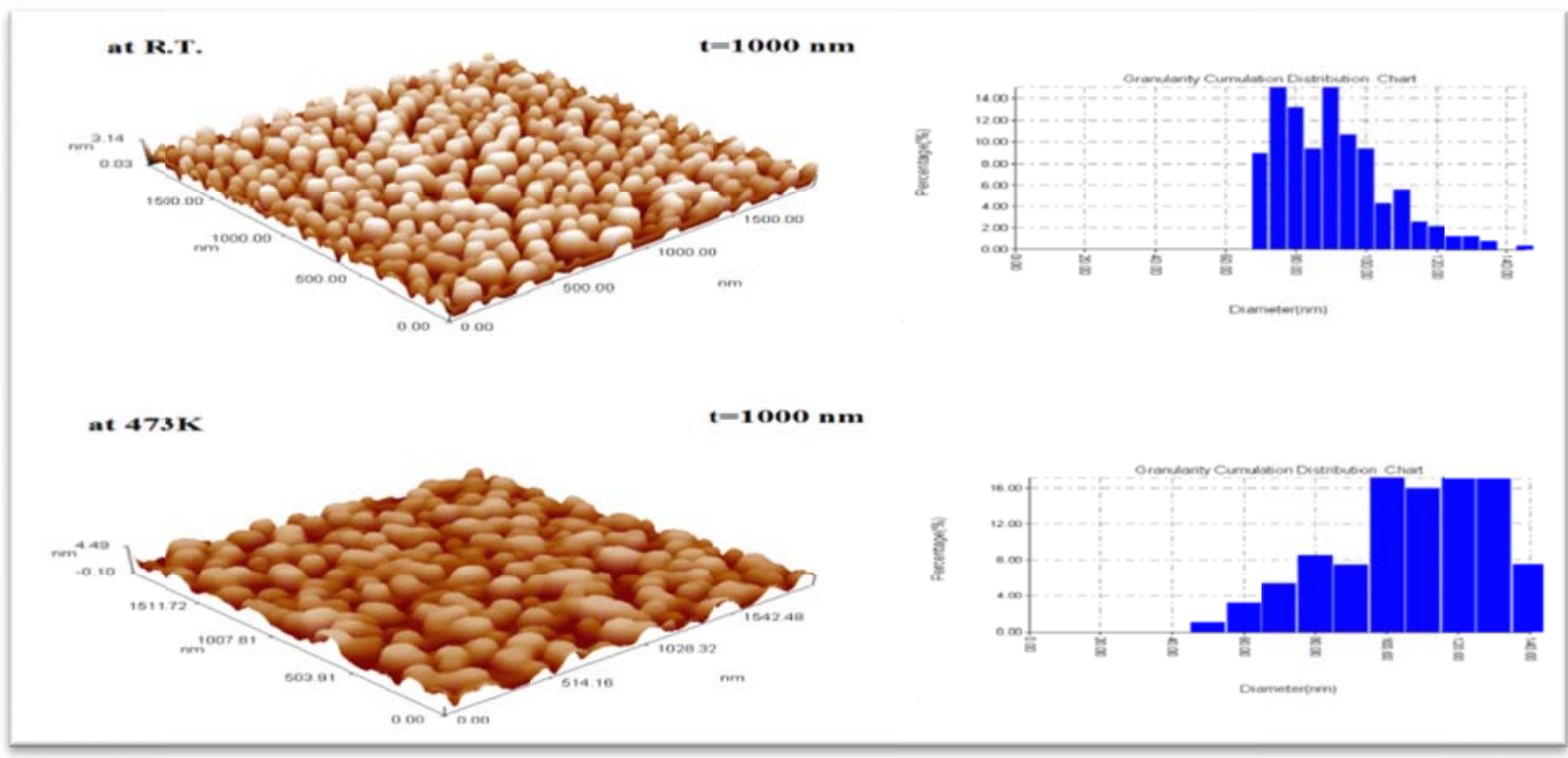

Fig. 5: AFM topography image of thin CTS films with $t=1000 \mathrm{~nm}$ that prapared at R.T. and annealed at $473 \mathrm{~K}$.

Table 4: Average grain size, average roughness, and root mean square for CTS.

\begin{tabular}{|c|c|c|c|c|}
\hline $\begin{array}{c}\text { Thickness } \\
(\mathbf{n m})\end{array}$ & $\begin{array}{c}\text { Temp. } \\
(\mathbf{K})\end{array}$ & $\begin{array}{c}\text { Grain Size } \\
(\mathbf{n m})\end{array}$ & $\begin{array}{c}\text { Average } \\
\text { Roughness(nm) }\end{array}$ & $\begin{array}{c}\text { Root Mean } \\
\text { Square (nm) }\end{array}$ \\
\hline \multirow{2}{*}{1000} & R.T. & $\mathbf{8 7 . 7 8}$ & 0.777 & 0.897 \\
\cline { 2 - 5 } & 473 & 102.02 & 0.712 & 0.819 \\
\hline
\end{tabular}

\section{Optical measurements}

The optical transmittance spectra of CTS thin films deposited at room temperature on glass substrates with different thicknesses $(500,750$ and 1000) $\mathrm{nm}$ and annealed at $473 \mathrm{~K}$, are shown in Fig. 6. From this figure, we can observed there is no interference fringes, this occurs due to the optical scattering phenomena in such film.

The transmittance of all deposited thin films increases with increasing of wavelength $(\lambda)$, and decrease with increasing films thickness from $500 \mathrm{~nm}$ to $1000 \mathrm{~nm}$, this occurs because increasing film thickness lead to decrease the defects 
and voids which result to increase the films absorption, as a result the transmittance decrease. The shift of transmittance toward higher wavelength with increasing thickness explains the shifting of the absorption edge towards lower energies.
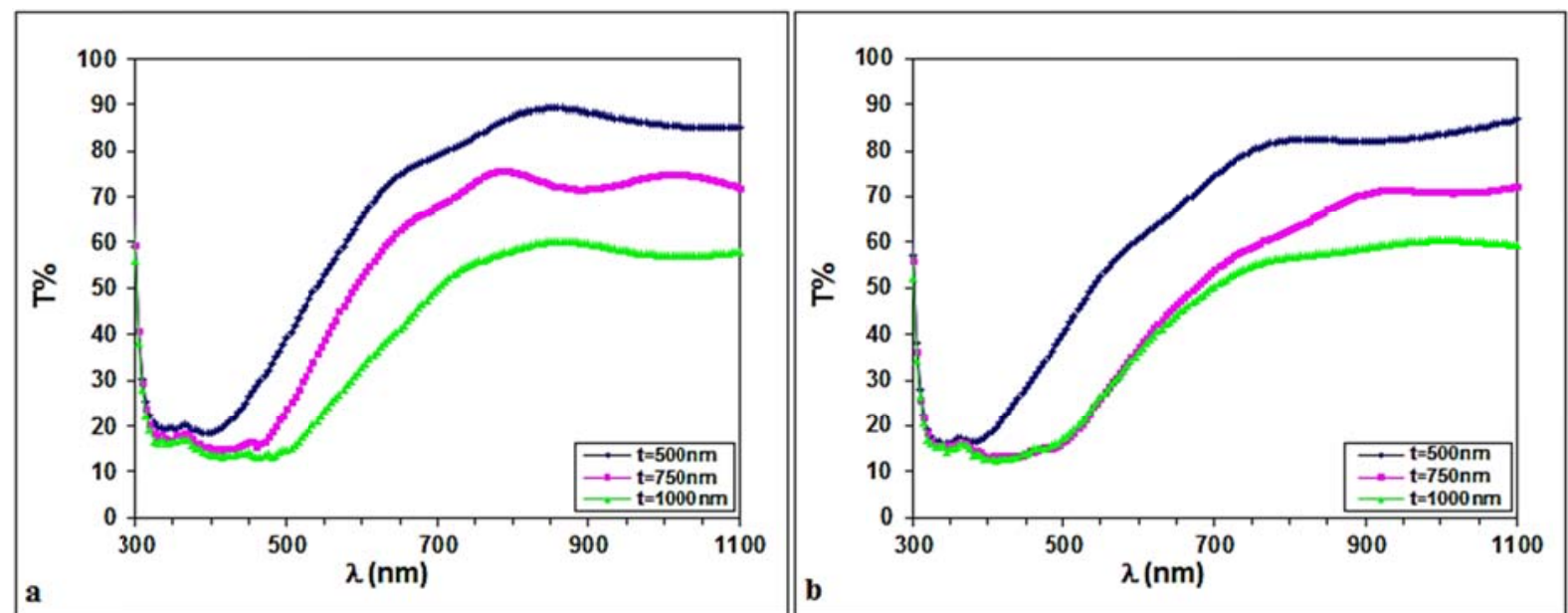

Fig. 6: The transmittance versus the wavelength for CTS films at different thickness a-as deposited b-annealed at $473 \mathrm{~K}$.

From Table 5 we can observe that the optical absorption coefficients for all films were fairly high values reached above $10^{4} \mathrm{~cm}^{-1}$, which means that there is a large probability of allowed direct transitions. The absorption coefficient dependence on the film thickness as a function of wave length for CTS films, it was notice from Table 5 that $\alpha$ increase with increasing films thickness for as deposited and annealed films.
In order to verify the nature of the band gap of $\mathrm{Cu}_{2} \mathrm{SnS}_{3}$, we plot $(\alpha h v)^{2}$ as a function of photon energy (hv) for as deposited and annealed films with different thickness $(500,750,1000) \mathrm{nm}$ as shown in Fig. $7 \mathrm{a}$ and $\mathrm{b}$ respectively.

The linear dependence in the high-energy range of the spectra observed in this plot indicated that $\mathrm{Cu}_{2} \mathrm{SnS}_{3}$ has a direct band gap. The optical energy gap decreases with increasing films thickness as cleared from Fig. 7 and Table 5.
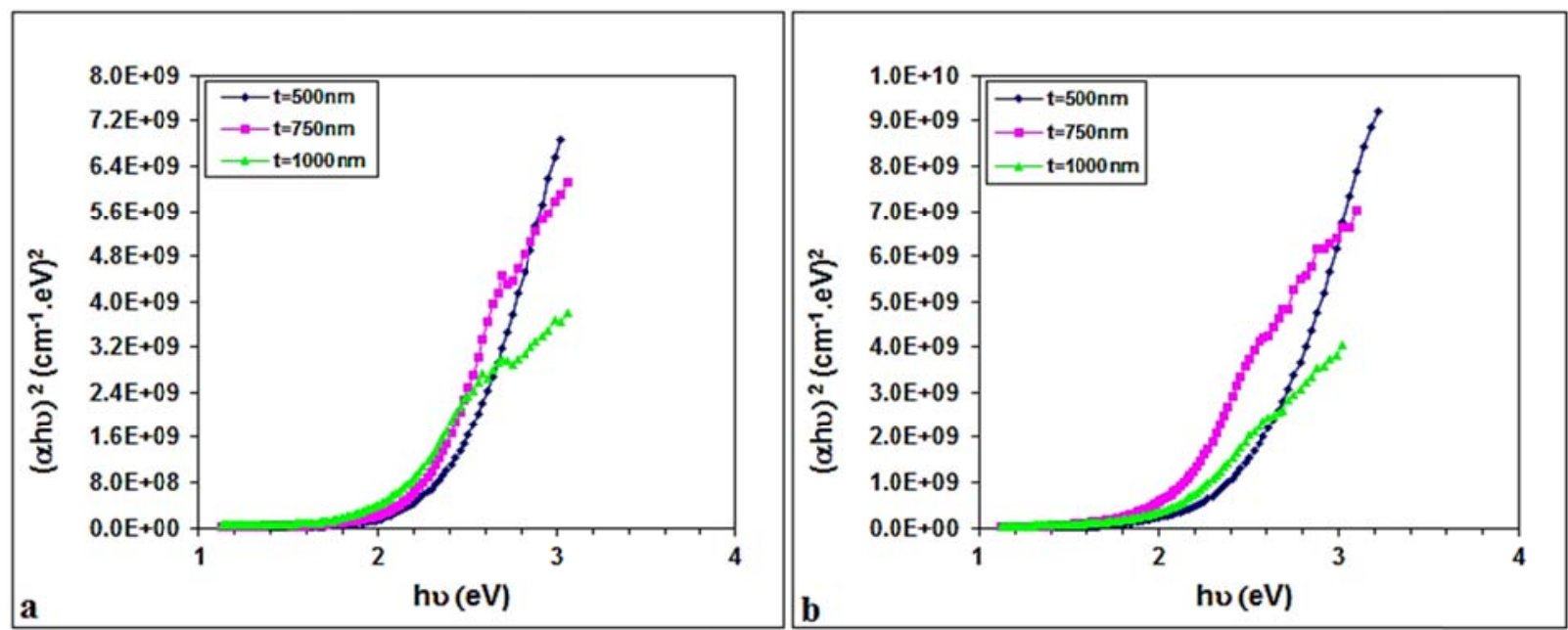

Fig. 7: The variation of (ahv) ${ }^{2}$ versus the photon energy (hv) for CTS films at different thickness a-as deposited b-annealed at $473 \mathrm{~K}$. 
It is obvious that the optical energy gap $\left(E_{\mathrm{g}}\right)$ decrease from $2.41 \mathrm{eV}$ to $1.92 \mathrm{eV}$ for $500 \mathrm{~nm}$, and $1000 \mathrm{~nm}$ respectively, the last result is approach to Zhao and Cheng results [9]. This decrement of $E_{g}$ with increasing thickness may be related to increase the absorption coefficient. $E_{g}$ decreasing by increase thickness because it is well known that $E_{g}$ value of bulk material is lower than that of film sample, that means there is a reduction occur in $E_{g}$ values, since the structure will be approach from that of bulk material. Generally, $E_{g}$ influence by annealing temperature where it increases when films annealed.

In general, the the extinction coefficient (k) increase for as deposited and annealed films at $473 \mathrm{~K}$ with thickness increasing due to increase of the grain size.
For as deposited CTS films, the refractive index (n) increased from 2.34 to 2.52 when thickness increased from 500 $\mathrm{nm}$ to $1000 \mathrm{~nm}$. $\mathrm{n}$ increased by annealing films at $473 \mathrm{~K}$.

It is obvios from Table 5 that the behavior of the real part of dielectric constant $\left(\varepsilon_{\mathrm{r}}\right)$ and imaginary part $\left(\varepsilon_{\mathrm{i}}\right)$ have the same as that of $n$ and $k$ respectively with the variation of thickness.

It can be observed that the real dielectric constant $\left(\varepsilon_{\mathrm{r}}\right)$ for as deposited CTS films increased from 5.48 to 6.39 by increasing thickness from $500 \mathrm{~nm}$ to 1000 $\mathrm{nm}$, while imaginary dielectric constant part $\left(\varepsilon_{\mathrm{i}}\right)$ increased from 0.158 to 0.26 for CTS films. Generally, $\varepsilon_{\mathrm{r}}$ and $\varepsilon_{\mathrm{i}}$ increase by increasing thickness.

Table 5: The values of $E_{g}{ }^{o p t}$ and optical constants at $\lambda=600 \mathrm{~nm}$ for as deposited and annealed CTS films with different thickness.

\begin{tabular}{|c|c|c|c|c|c|c|c|c|}
\hline Alloys & $\begin{array}{c}\text { Thickness } \\
\text { (nm) }\end{array}$ & Temp.(K) & $\begin{array}{l}\mathrm{E}_{\mathrm{g}}{ }^{\text {opt. }} \\
(\mathrm{e} \mathrm{V})\end{array}$ & $\begin{array}{l}\alpha * 10^{4} \\
\left(\mathrm{~cm}^{-1}\right)\end{array}$ & $\mathrm{n}$ & $\mathrm{k}$ & $\varepsilon_{\mathrm{r}}$ & $\varepsilon_{\mathrm{i}}$ \\
\hline \multirow{6}{*}{$\mathrm{Cu}_{2} \mathrm{SnS}_{3}$} & \multirow[t]{2}{*}{500} & R.T. & 2.41 & 0.707 & 2.34255 & 0.03148 & 5.48641 & 0.15806 \\
\hline & & 473 & 2.52 & 0.83 & 2.44435 & 0.03962 & 5.973304 & 0.19372 \\
\hline & \multirow[t]{2}{*}{750} & R.T. & 2.22 & 0.853 & 2.578654 & 0.04071 & 6.64779 & 0.20995 \\
\hline & & 473 & 2.05 & 1.31 & 2.6085 & 0.06255 & 6.800408 & 0.32633 \\
\hline & \multirow[t]{2}{*}{1000} & R.T. & 1.92 & 1.11 & 2.528997 & 0.05322 & 6.39299 & 0.26919 \\
\hline & & 473 & 1.97 & 1.01 & 2.59411 & 0.04841 & 6.72707 & 0.2512 \\
\hline
\end{tabular}

\section{Conclusions}

Effect of film thickness and annealing temperature on the structural, morphological, and optical properties of $\mathrm{Cu}_{2} \mathrm{SnS}_{3}$ films deposited by flash thermal evaporation technique were investigated. X-ray diffraction study of the CTS 1. powder shows that this material crystallizes in cubic structure. The structures of as deposited films have amorphous structure and improve with 2 . annealing. AFM measurement showed that the average grain size increase with 3 . annealing. The results of the optical characterization revealed that the CTS films of thickness $1000 \mathrm{~nm}$ have low transmittance in the visible range. The 4. results also revealed that the $\mathrm{Cu}_{2} \mathrm{SnS}_{3}$ films have direct band gap of about
$1.92 \mathrm{eV}$. This indicates that these films are active in the visible portion of the spectrum and could be employed as absorber layer in the solar cells.

\section{References}

[1] Q. Chen and Di Ma, Hindawi Publishing Corporation International Journal of Photoenergy, 2013 (2013) Article ID 593420, 1-5.

[2] M. Adelifard, M. Mohagheghi, H. Eshghi, Phys. Scr., 85 (2012) 1-4.

[3] X. Liang, Q. Cai W. Xiang, Z. Chen, J. Zhong, Y. Wang, M. Shao, Z. Li, J. Mater. Sci. Technol., 29, 3 (2013) 231236.

[4] Y. Zhai, S. Chen, J.Yang, H. Xiang, X. Gong, A. Kang, S. Wei, Physical Review, 84 (2011) 075213. 
[5] P. Fernandes, P. Salomé, A. da Cunha, Physical Review, 84, 7 (2011) 1-6.

[6] J. Han, Y. Zhou, Y.Tian, Z. Huang, X. Wang, J. Zhong, Z. Xia, B. Yang, H. Song, J. Tang, front. Optoelectrron, Springer - Verlage Berline Heidelberg, (2014).

[7] T. Nomura, T. Maeda, T. Wada, 5. Japanese Journal of Applied Physics, 53 (2014) 1-6.

[8] M. Berg, R. Djemour, L. Gütay, G. 6. Zoppi, S. Siebentritt, P. Dominik, Thin Solid Films, 520 (2012) 6291-6294.

[9] P. Zhao and S. Cheng, Hindawi Publishing Corporation Advances in Materials Science and Engineering, 2013 (2013), Article ID 726080, 1-4.
[10] V. L. Shaposhnikova, A. V. Krivosheevaa, V. E. Borisenkoa, J.-L. Lazzarib, Science Jet, 520, 19 (2012) 1-15 [11] N.Aihara, A. Kanai, K. Kimura, M. Yamada, K. Toyonaga, A. Takeuchi, H. Katagiri, Japanese Journal of Applied Physics, 53 ( 2014) 012301.

[12] Devendra Tiwari, T. K. Chaudhuri, T. Shripathi, and U. Deshp, AIP Conf., 1447 (2012) 1039-1040.

[13] M.Dominik Berg, R. Djemour, L. Gutay, S. Siebentritt, P. Dale, X.Fontane, V. Izquierdo-Roca, A. Pe'rez-Rodriguez, Applied Physics Letter, 100 (2012) 192103. 